\title{
Substituciones en la unidad D-Galactosa de polímeros del agar: Implicaciones metabólicas
}

\author{
Substitutions on the D-Galactose unit of agar polymers: Metabolic implications \\ Mauricio A. Ondarza ${ }^{1}$ \\ ${ }^{1}$ Departamento de Ingeniería Ambiental. Unidad Académica Multidisciplinaria Reynosa Rodhe. Reynosa, Tam, Universidad \\ Autónoma de Tamaulipas, Carretera a San Fernando cruce con canal Rodhe s/n. México \\ mondarza@uat.edu.mx
}

\begin{abstract}
Regarding macroalgae's physiology, it is considered that substitutions on the L-Gal unit of agar polymers are representative of their biosynthesis. Studies performed within the Plant Cell Wall Polysaccharides Laboratory team have demonstrated the presence of 4-Omethyl-L-galactose in agar polymers from the rhodophycean thallophyte Gracilaria verrucosa and its linkage on the C-6 position of the D-Gal unit, which is also the site of O-
\end{abstract}

methylation. Based on the 6-O-Me-Gal/ 4-O-Me-Gal ratio and the degree of substitution of D-Gal unit, a new approach for monitoring the characteristic events of agar metabolism was defined.

Key words: Agar, Gracilaria verrucosa, biosynthesis, Omethylation

\section{Introducción}

El agar ha sido definido como una secuencia regular alternante entre unidades: $3-O-\beta$-D-galactopiranosa y 4-O-3,6-anhidro- $\alpha$-L-galactopiranosa (Araki C 1967) y es igualmente considerado como una familia de galactanos que difieren en su variedad, extensión y en las proporciones relativas de las substituciones en la unidades galactosa (Duckworth \& Yaphe 1971). Es así como ambas unidades D y L pueden ser substituidas con metil-éteres (C-6 en la unidad D, C-2 de la unidad L) y con esteres de sulfato (C-2, C-4 y C-6 de la unidad L). El mayor tipo de sulfatación ocurre como $\alpha$-Lgalactosa-6-sulfato (L-Gal-6-sulfato) que puede ser convertido a 3,6-anhidro- $\alpha$-L-galactopiranosa (3,6-AG), por vía enzimática, química o por tratamiento con álcalis. Se considera a este polímero sulfatado como el precursor biológico de la agarosa, representando la única etapa hasta ahora reportada en la biosíntesis de polímeros del tipo agar.

La aplicación de condiciones de cultivo controlado, junto con la disponibilidad de especies bien definidas taxonómicamente, han conducido a resultados que establecen la influencia de parámetros como: la intensidad luminosa, la temperatura y el aporte de nutrientes, en la calidad del agar. Se ha sugerido que la heterogeneidad y complejidad del agar pudiera reflejar actividades metabólicas (Asare 1980, Bird et al. 1981).

Considerando la presencia novedosa de cadenas laterales simples de 4-O-metil galactosa (4-O-Me-Gal) que modifica la definición del agar como cadena lineal polimérica, se decidió seguir la evolución de polímeros del agar y su metabolismo, a través de cultivos controlados, y la comparación de su composición química con la de plantas nativas en su estado natural.

\section{Material y métodos}

\section{Condiciones de cultivo controlado}

Gracilaria verrucosa (Hudson) Papenfuss fue recolectada en el cabo Nariz Gris (noreste de Francia). El material vegetal se dividió en tres partes: a) material nativo en su estado inicial, b) muestra II y c) muestra III, las cuales fueron sometidas a dos condiciones de cultivo: promotoras de crecimiento (CPC) y no promotoras de crecimiento (CNPC).

\section{Condiciones promotoras de crecimiento (CPC)}

Segmentos de ejes primarios centrales (EC) y de ramificaciones laterales (RL) de $5 \mathrm{~cm}$ de longitud, obtenidas a partir de la muestra II, fueron aclimatados a intensidades luminosas semejantes a las imperantes en el verano. La irradiación se fijó en $62 \mathrm{mE} \mathrm{m}^{-2} \mathrm{~s}^{-1}$ (lámparas incandescentes Gros-lux y fluorescentes 
Cool-white). El fotoperíodo fue programado en un ciclo 16:8 h (luz: oscuridad). La temperatura se mantuvo en $24 \pm 2^{\circ} \mathrm{C}$. El aire fue suministrado al acuario. El medio consistió en agua de mar natural $(3 \mathrm{~L})$, enriquecida con medio Provasoli y era cambiada cada semana. La concentración final de $\mathrm{NaNO}_{3}$ fue de $8 \mathrm{mM}$. Las tasas de crecimiento se determinaron mediante la medición del peso fresco (PF). El peso seco (PS) se estableció posterior a una liofilización del material. El cultivo se llevó a cabo durante un período de dos meses.

\section{Condiciones no promotoras del crecimiento (CNPC)}

Tanto (EC) como (RL) de $5 \mathrm{~cm}$ de longitud fueron sometidos a intensidades luminosas de irradiación propias de las condiciones naturales del invierno (17

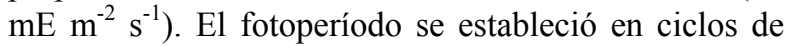
8:16 h (luz: oscuridad). La temperatura fue de $5^{\circ} \mathrm{C}$. El medio consistió en $3 \mathrm{~L}$ de agua de mar natural cambiada una vez por semana durante dos meses. El crecimiento se estableció como ya se describió anteriormente.

\section{Extracción}

La comparación previa de extracciones en agua (Christiaen et al. 1987) y en mezclas de etanol/ agua (Lahaye et al. 1986), permitieron desarrollar un nuevo procedimiento (Ondarza et al. 1987). La Fig. 1 muestra la ruta de extracciones con agua para demostrar la heterogeneidad del agar.

Se pulverizaron los segmentos vegetales ya mencionados hasta tomar $5 \mathrm{~g}$ de cada uno y se sometieron a doble destilación en agua destilada (1L, $12 \mathrm{~h})$ a $22^{\circ} \mathrm{C}$. Se recuperó el extracto crudo (EC) mediante filtración en membranas de nitrocelulosa $(8,3$ y $45 \mathrm{~mm}$; Sartorius) y liofilización. El material crudo (MC), previamente tratado con acetona y etanol, fue sometido a extracción con agua destilada $(300 \mathrm{~mL})$ a $60^{\circ} \mathrm{C}$ durante 1 hora (A60), seguido de esterilización en autoclave $\left(121^{\circ} \mathrm{C}, 1 \mathrm{~atm}\right)$ en $300 \mathrm{~mL}$ de agua destilada por 3 y $1 \mathrm{~h}$, respectivamente (A121). El residuo algal (RA) también fue liofilizado.

\section{Caracterización de carbohidratos constituyentes y sus cantidades relativas}

Los carbohidratos totales fueron determinados por el método del orcinol-ácido sulfúrico empleando galactosa como estándar. El contenido de 3,6-AG se estableció por el método del resorcinol usando fructosa como estándar. El contenido en sulfato se determinó mediante HPLC (cromatografía líquida) empleando una columna Rosil AN (Altech) y un monitor de conductividad (Milton Roy), de acuerdo a la metodología descrita por Karamanos et al. (1988). Los carbohidratos neutros fueron cuantificados siguiendo la metodología descrita por Sloneker (1972). Su identificación se basó en los tiempos de retención (relativos a carbohidratos conocidos) y a sus espectros de masa. El 6-O-Me-Gal fue aislado a partir de Porphyra umbilicalis mientras que el 4-O-Me-Gal fue proporcionado por el Dr. JS Craigie (q.e.p.d.). Los cálculos sobre la composición molar se establecieron de acuerdo a los siguientes criterios: el L-Gal total se definió como el L-Gal-6-sulfato más el contenido en 3,6-AG; el D-Gal total se obtiene de la suma de concentraciones molares tanto del D-Gal como del 6O-Me-Gal. La hipótesis de trabajo establece que la cantidad de sulfato estimada por HPLC representa el contenido total en L-Gal-6-sulfato.

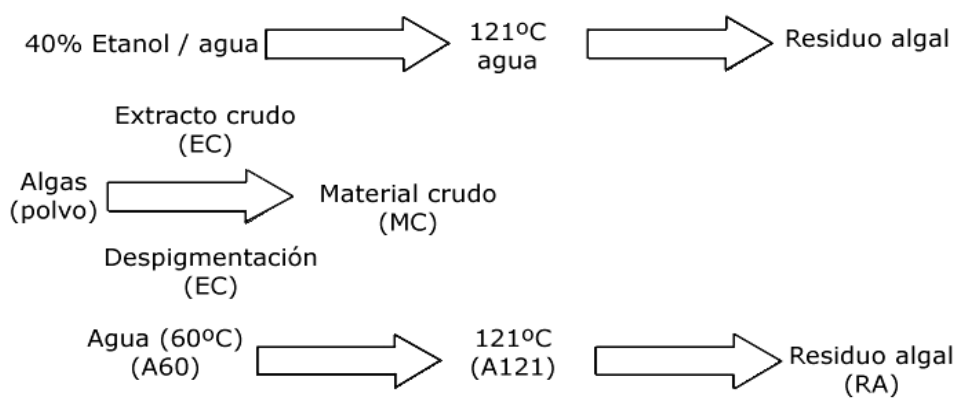

Figura 1

Procedimiento simplificado de extracción del agar en Gracilaria verrucosa 


\section{Resultados y discusión}

Las condiciones promotoras de crecimiento (CPC) favorecieron la producción de la biomasa (incremento en peso fresco en $\mathrm{g} /$ día de un 8 a un $12 \%$ a la semana) tanto para los segmentos vegetales de las ramificaciones laterales (RL), como para los ejes primarios centrales (EP). Los polisacáridos extraídos con el solvente agua a altas temperaturas $\left(121^{\circ} \mathrm{C}\right)$, representaron de un 17 a un $20 \%$ de peso en materia seca tanto para las ramificaciones laterales (RL) como para los ejes primarios (EP). En el caso de explantes bajo condiciones no promotoras del crecimiento (CNPC), la biomasa se mantuvo estable y los rendimientos en las extracciones de polisacáridos obtenidos fueron de un 20 hasta un 30\% respectivamente para RL y EP.

Las gráficas siguientes permiten visualizar de mejor manera: el patrón de substitución (6-O-Me-Gal y 4-OMe-Gal), el cociente $(\alpha)$ (6-O-Me-Gal/ 4-O-Me-Gal) y, el grado total de substitución $(\delta)$ para C-6 de la unidad D-Gal. En la Fig. 2 se ilustra la "gráfica de calidad" de este material crudo (MC) obtenido durante diferentes condiciones de cultivo. Se observa que los polímeros altamente substituidos son obtenidos bajo condiciones promotoras del crecimiento $(\delta>0,4)$ y que la buena calidad se obtiene con condiciones no promotoras, particularmente en el caso de las ramificaciones laterales $(\mathrm{RL})(\delta=0,1)$.

Comparado con las plantas nativas, la extracción de polisacáridos solubles a temperaturas altas mostró patrones de substitución similares a los obtenidos bajo condiciones no promotoras de cultivo, con ligero incremento en el contenido de 6-O-Me-Gal en las ramificaciones laterales. Esto no es sorprendente dado que las plantas nativas se recolectaron en condiciones de invierno, bajo condiciones climáticas parecidas a las establecidas para las condiciones no promotoras del crecimiento (CNPC).

Los verdaderos cambios ocurrieron durante condiciones promotoras del crecimiento (CPC), con incrementos en las concentraciones molares en residuos 4-O-Me-Gal (principalmente en ejes primarios centrales). Un mismo patrón de substitución fue finalmente obtenido para ambos segmentos vegetales $(\delta=0,47)$. Dichos resultados sugieren que un intercambio continuo puede existir entre las diferentes formas de la unidad D-Galactosa durante el crecimiento del alga.

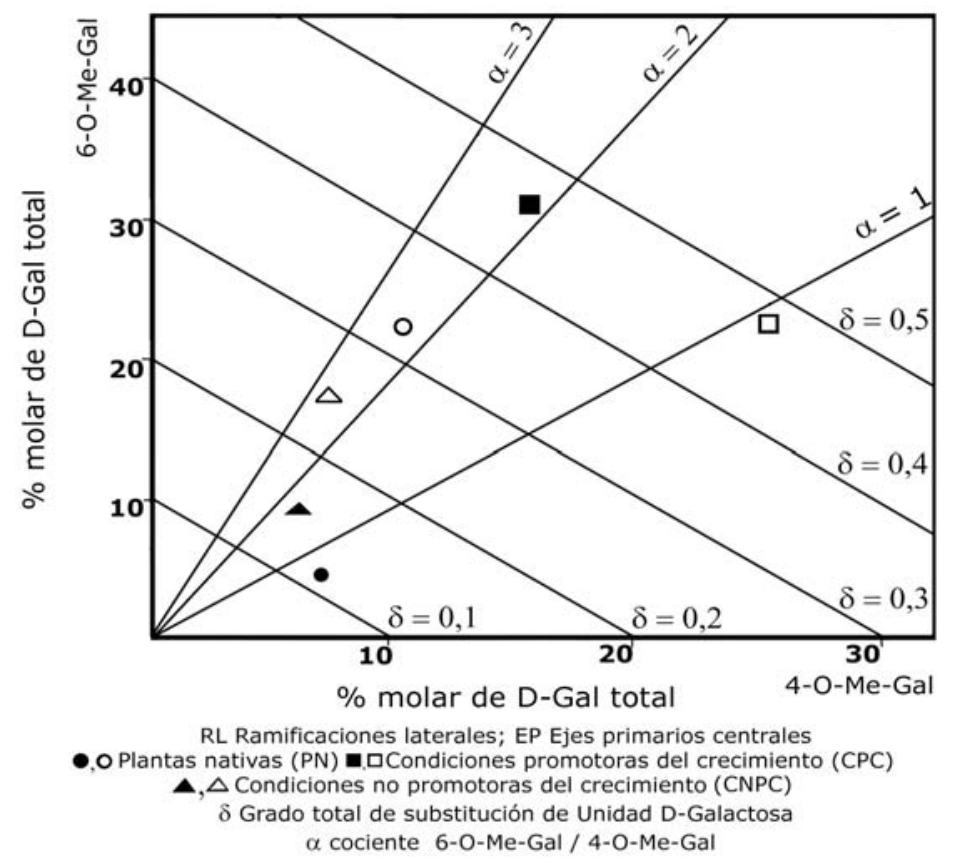

Figura 2

Gráfica de calidad del material crudo obtenido bajo las diferentes condiciones de cultivo

Quality data of the raw material obtained under the different culture conditions 
El residuo algal (RA) presenta mayor contenido en residuos 4-O-Me-Gal. Este carbohidrato parece pertenecer al tipo de polisacáridos neutros adheridos firmemente a la pared celular y presenta por lo tanto una baja extractibilidad (resultados confirmados por cromatografía de intercambio iónico en columna DEAE - Sephadex, en donde se obtienen mayoritariamente fracciones enriquecidas con residuos 4-O-Me-Gal).

Los cambios en la composición del agar documentados aquí, pueden ser interpretados como el resultado de actividades metabólicas de las células. Queda por establecer si este intercambio continuo es un efecto del anabolismo o es el resultado de una degradación, seguida por una síntesis de novo de polímeros substituidos en mayor o menor grado. El aislamiento de las enzimas que intervienen en este fenómeno, dará una respuesta a nuestra hipótesis (Karamanos et al. 1989).

\section{Agradecimientos}

El autor agradece a las autoridades del Consejo Nacional de Ciencia y Tecnología (CONACYT), por la beca de estudios del doctorado obtenido en la Universidad de Tecnología de Compiegne, Francia, en la especialidad de Ingeniería Biológica (tesis U-15), en octubre de 1988, a través del VIII Programa de Intercambio Científico México-Francia (CEFI), 19841988. Deseo agradecer a los evaluadores, por sus observaciones, sugerencias y por su calidad profesional.

\section{Literatura citada}

Araki C, K Arai \& S Hirase. 1967. Studies on the chemical constitution of agar-agar. XXIII. Isolation of D-xylose, 60-methyl-D-galactose, 4-0-methyl-L-galactose and Omethyl-pentose. Bulletin of the Chemical Society of Japan 40: 959-962.

Asare SO. 1980. Seasonal changes in sulphate and 3.6- anhydro-galactose content of phycocolloids from two red algae. Botanica Marina 23: 595-598.

Bird KT, MD Hanisak \& J Ryther. 1981. Chemical quality and production of agars extracted from Gracilaria tikvahiae grown in different nitrogen enrichment conditions. Botanica Marina 24: 441-444.

Christiaen D, T Stadler, MA Ondarza \& MC Verdus. 1987. Structures and functions of the polysaccharide from the cell wall of Gracilaria verrucosa (Rhodophyceae, Gigartinales). Hydrobiologia 151/152: 139-146.

Duckworth M \& W Yaphe. 1971. The structure of agar. Part 1. Fractionation of a complex mixture of polysaccharides. Carbohydrate Research 16: 189-197.

Karamanos Y, MA Ondarza, H Morvan, T Stadler \& D Christiaen. 1988. Polysaccharides (Convenors: S. Arad and D. Christiaen). Metabolic Implications of 4-0methyl-L-galactose substitutions on the D-galactose unit in agar polymers. En: Stadler T, J Mollion, MC Verdus, Y Karamanos, H Morvan \& D Christiaen (eds). Algal Biotechnology, pp. 477-487. Elsevier Applied Science Publishers Ltd., New York and London.

Karamanos Y, MA Ondarza, F Bellanger, D Christiaen \& S Moreau. 1989. The linkage of 4-O-methyl-Lgalactopyranose in the agar polymers from Gracilaria verrucosa. Carbohydrate Research 187: 93-101.

Lahaye M, C Rochas \& W Yaphe. 1986. A new procedure for determining the heterogeneity of agar polymers in the cell walls of Gracilaria sp. (Gracilariaceae, Rhodophyta). Canadian Journal of Botany 64: 579-585.

Ondarza M, Y Karamanos, D Christiaen \& T Stadler. 1987. Variations in the composition of agar polysaccharides from Gracilaria verrucosa, cultivated under controlled conditions. Food Hydrocolloids 1 (5/6): 507-509.

Sloneker JH. 1972. Gas-liquid chromatography of alditol acetates. En: Whistler RL \& JN Bemiller. Methods in Carbohydrate Chemistry 6: 20-24. Academic Press, New York. 